\title{
Developing of Supplementary Books of Mathematics Teaching-Learning Process Based-on Coastal Culture for JHS Students
}

\author{
Zaenuria $^{a}$, Hardi Suyitno ${ }^{a}$, Fathur Rokhman ${ }^{a}$ and Amin Suyitno ${ }^{a}$
}

aUniversitas Negeri Semarang, INDONESIA

ABSTRACT

The coastal area is a residential area of fishermen. In general, kids of fishing families only elementary schools. Therefore, children need to be motivated to be willing to continue their study in junior high school. Thus, needs and should be made a textbook based-on the coastal culture for junior high school (JHS), which was preceded by research activities. The purpose of this study to make the models of supplementary book of mathematics teaching-learning process based-on coastal culture for JHS students. This research activity was a qualitative research. The activities as follows: (1) exploring the coastal culture that can be used as a means to clarify concepts or materials about math, (2) By Focus Group Discussion activity, was prepared a draft of supplementary books of mathematics teaching-learning process based on coastal culture for JHS students. The result is the model of supplementary book of mathematics teaching-learning process based-on coastal culture for JHS students. The conclusion is that mathematics can have benefits in the lives of fishermen, it is expected that the school could become the foundation for improving the pattern of community life of the fishermen environment in the future for their children.

KEYWORDS

coastal culture, mathematics, textbook
ARTICLE HISTORY

Received 15 November 2016

Revised 22 February 2017

Accepted 26 February 2017

\section{Introduction}

Indonesia is an archipelago. Children of fishermen families need to be motivated and nurtured so that the children want to go to school and feel that school is a necessity of life in the future. Therefore, we have compiled a textbook based on coastal culture, especially for math. Compilation textbooks like this should be preceded by a research. Therefore, should be considered the

\section{CORRESPONDENCE Zaenuri $\square$ zaenuri.mipa@mail.unnes.ac.id}

\section{(C) 2017 Zaenuri et al.}

Open Access terms of the Creative Commons Attribution 4.0 International License apply. The license permits unrestricted use, distribution, and reproduction in any medium, on the condition that users give exact credit to the original author(s) and the source, provide a link to the Creative Commons license, and indicate if they made any changes. (http://creativecommons.org/licenses/by/4.0/) 
complement books for Junior High School (JHS) of mathematics based on the coastal culture.

Hopefully, with mathematics learning process based on coastal culture for Junior High School students will increase student interest. Uzoğlu and Büyükkasap (2011) in their study wrote that there was a positive correlation between interpersonal and intrapersonal with math learning achievement. Thus, interpersonal and intrapersonal relationships were also the work of parents as fishermen reasonable if it can affect their son or daughter to continue their study.

The increase of interest in learning mathematics, in turn, is expected to improve student achievement in our country. Local culture especially at coastal culture, many involved with the daily activities of human. Freudenthal (1991) wrote that mathematics must be connected to reality; mathematics as human activity. This thinking was in line with Suyitno (2014) who said that mathematics has a relationship with the real world and the local cultures. Figure 1 shows the atmosphere of the daily life of a family of fishermen. They pay less attention to their children's needs for schooling.

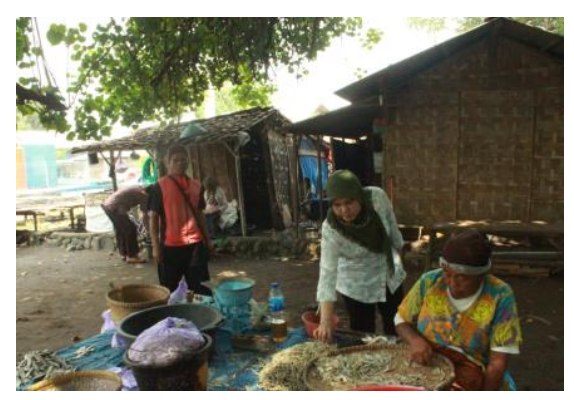

Figure 1. The daily life of the fishermen family so that they do not pay attention to the importance of education (Resource: Documentation of Research Team at Coastal of Kendal - Indonesia)

Therefore, the research was expected to result the book product of the mathematics teaching-learning process based-on coastal culture for JHS students, so this research deserves to be done. Güzel (2004) wrote that the results of a scientific research affect the development of science and is widely used in everyday life. Thus, if a study can show that mathematics can have benefits in the lives of fishermen, it is expected that the school could become the foundation for improving the pattern of community life the fishermen environment in the future for their children.

\section{Learning Innovations Based on Coastal Culture as a Novelty}

Each teacher is required to innovate learning by selecting and developing learning models, which involves strategies, methods, and approaches of learning. Curriculum of 2013 explicitly introduces three (3) models of innovative learning models, such as problem-based learning, project based learning, or inquiry-based learning.

Learning innovations that teachers do in line with the view of Gagne (1983). According to Gagne, there were four functions to be performed so that 
the teacher can be a motivator for students, namely (1) generate the urge of students to learn (arousal function), (2) explain in concrete terms to the student what to do at the end of the lesson (expectancy function), (3) reward for the achievements of students to stimulate subsequent achievement (incentive function), and (4) assist the regularity of student behavior (disciplinary function).

Learning innovations that teachers need the support of adequate teaching materials based on coastal culture. According to UNESCO (1998), development of teaching materials can be divided into several components, as presented in Table 1.

Table 1. Component Framework for Development of Teaching Material

\begin{tabular}{|c|c|c|}
\hline No & Component & Explanation \\
\hline 1. & Needs assesment & $\begin{array}{l}\text { Looking for the needs of students so that teachers can } \\
\text { provide appropriate material based on coastal culture. }\end{array}$ \\
\hline 2. & $\begin{array}{l}\text { Determining goals and } \\
\text { objectives }\end{array}$ & $\begin{array}{l}\text { What exactly is the purpose of learning and what students } \\
\text { need or how the student achieve that goal. }\end{array}$ \\
\hline 3. & $\begin{array}{l}\text { Selecting and developing } \\
\text { materials and activities }\end{array}$ & $\begin{array}{l}\text { Selecting and developing materials, including activities, how } \\
\text { and in what ways can teachers teach? What is the role of } \\
\text { teachers and students }\end{array}$ \\
\hline 4. & $\begin{array}{l}\text { Organization of content } \\
\text { and activities }\end{array}$ & $\begin{array}{l}\text { How do the teachers manage the contents and activity in } \\
\text { learning process based on coastal culture? }\end{array}$ \\
\hline 5. & Evaluation & $\begin{array}{l}\text { How do the teachers assess what students have learned? } \\
\text { How do teachers assess the effectiveness of learning process? }\end{array}$ \\
\hline 6. & $\begin{array}{l}\text { Concideration of resources } \\
\text { and constrains }\end{array}$ & $\begin{array}{l}\text { Considerations and other sources are used, what is the } \\
\text { benefit of this kind of situation. }\end{array}$ \\
\hline
\end{tabular}

Based on Table 1 above, the framework of the development of teaching materials based on components can present a complex process becomes more structured and organized, making it easier to be done and domain of question for teachers is more easily solved. Thus, the novelty value of this study can show that mathematics can have benefits in the lives of fishermen, it is expected that the school could become the foundation for improving the pattern of community life the fishermen environment in the future for their children.

\section{Coastal Culture as the Part of Local Culture}

Development of teaching materials should be integrated with local cultural values because education is a process of acculturation and education is also seen as a tool for cultural change. Learning process is a formal process of acculturation. The process of acculturation is not merely cultural transmission and cultural adoption but also cultural change. Culture based learning is not something new, but today is emerging in many countries. Coastal culture is the part of local culture. In a culture based learning, learning environment will be transformed into a pleasant environment for teachers and students, which allows teachers and students to participate actively by the culture they are familiar with, so as to obtain optimal learning results. Students feel happy and 
recognized the existence of and the differences, because the knowledge and experience of a very rich culture that they have to be recognized in the learning process. Teachers play a role to guide and direct the students to explore the potential of cultural diversity that is already known, as well as develop the culture. According to Wang (2011), Howell (2008), and Gomez (2007), the interaction of teachers and students will accommodate the creation of meaning from knowledge gained in subjects in school by each individual.

Bishop (1994) revealed that all formal mathematics education is a process of cultural interaction and every student to experience the culture in the process. Thus, formal mathematics education in schools can not actually be released from various cultural phenomena surrounding it. Freudental (1991) said, "Mathematics must be connected to reality" (mathematics should be close to the learners and to be associated with everyday life situations) ". Schoenfield (1987 and 1992) pointed out, "the world of mathematics culture" will encourage students to think about mathematics as an integral part of everyday life, improve students' skills in making or doing linkages between mathematics concepts in different contexts, and build understanding in the student environment by solving math problems either independently or together.

Research results of Nutti (2013) showed, the application of mathematics (mathematics based-on ethnomathematical content) as a means to motivate, stimulate students, can overcome boredom and give a new feel to the learning of mathematics. Research publications of Uloko and Imoko (2007) asserted, the success of Japan and China in mathematics because they use mathematics based on local culture. This research was in line with research conducted by Gerdes (1988 and 1996), Eraslan (2014), Nadjafikhah, et al (2012), and Lipka and Irhke (2009).

\section{Steps of Research to Obtain the Textbook}

\section{Research Approach}

This research used a research method with the qualitative approach, which has the characteristics of a natural setting as the data source directly, descriptive and more important process to obtain accurate results. The analysis in this qualitative research tends conducted inductive analysis and meaning are essential.

\section{Preliminary Study}

At the phase of preliminary was planned as follows: literature study, data collection, description, and analysis of the findings in the field.

\section{Making a draft of Model and Collaboration Activity}

Based on the description and analysis of the findings in a factual, then compiled the development steps as follows. (1) Exploring forms of coastal cultures and their relation to mathematics concepts. (2) Developing of mathematics teaching-learning process based-on coastal culture for JHS students. (3) Developing a design of teaching materials of mathematics based on coastal culture in FGD or Focus Group Discussion. (4) Improving the design of teaching materials of mathematics based on coastal culture with the supervisor from the experts. FGD involves collaborative activity between research team with lecturer partners of UKM (Universiti Kebangsaan Malaysia). 


\section{Technique of Analysis Data}

Activities in the analysis of the data include: data reduction, data display, data interpretation, conclusion and verification. In the data reduction, researchers can add, subtract, or complement of data. Presentation of data is a process of gathering information, sorted by categories or groupings that required. Interpretation of the data was the process of understanding the meaning of a set of data that has been presented. Taking a conclusion/verification was the process of formulation of the meaning of the study done with a short sentence, solid, and easy to understand, relevan, and consistency with the title, purpose, and formulation of the problem.

\section{Indicators of Accomplishment}

The research results indicators are as follows. (1) Be able to revealed the exploration of coastal culture. (2) Be able to develop of mathematics teachinglearning process based-on coastal culture for School students. (3) Composed the design of school mathematics teaching-learning process based-on coastal culture for School students in FGD. (4) Produced the product of the model of supplementary books of mathematics teaching-learning process based-on coastal culture for School students, and has ISBN.

\section{The Results Achieved}

Research activities that have been implemented were as follows. (1) Has implemented data collection related to the preparation of the draft of the model of supplementary books of mathematics teaching-learning process based-on coastal culture for JHS students. (2) Make a draft of the model of supplementary books of mathematics teaching-learning process based-on coastal culture for JHS students. (3) Make a visit to Universiti Kebangsaan Malaysia (UKM) and discussions with researcher partner to seek the common perception about the contents of the draft of the model of supplementary books of mathematics teaching-learning process based-on coastal culture for School students. (4) Through Focus Group Discussion (FGD), successfully established a result of research namely the model of supplementary books of mathematics teachinglearning process based-on coastal culture for JHS students. (5) A limited test of the effectiveness of the use of the models of supplementary books of mathematics teaching-learning process based-on coastal culture for JHS students at a junior high school had been conducted.

\section{Part of Math Textbook Base-On Coastal Culture}

\section{Preface}

Indonesia is an archipelago. Children from the fishermen families do not go to school or do not continue their education. Thus, a family of fishermen need to be motivated and nurtured so that their children can go to school and feel that the school is a necessity of life in the future. Therefore, we have made a textbook based coastal culture, especially for math. Compilation of textbooks like this must be preceded by a research. Therefore, this mathematics supplementary book for junior high school is based on the results of the research study. Figure 2 shows the bustle of the family to look for fish. They do not have time to pay attention to their children's education. School is considered to no support for their work in catching fish in the sea. 


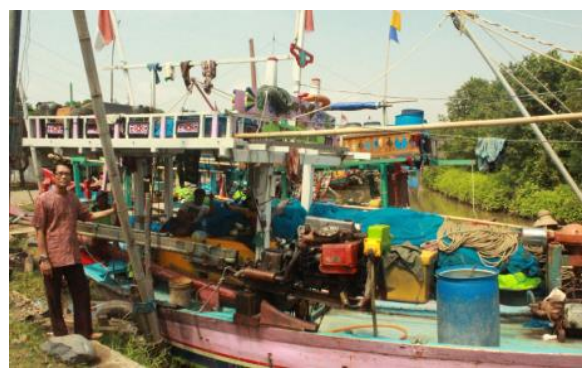

Figure 2. The daily life of the fishermen family so they do not pay attention to the importance of education (Resource: Documentation of Research Team at Coastal of Sikucing - Indonesia)

Hopefully, with this book then the result of mathematics learning to middle school kids in the coastal area can be increased and motivated to learn. The increasing interest in mathematics, in turn, is expected to improve student achievement in our country, especially the children in the coastal areas. Freudenthal (1991) wrote that mathematics is to be associated with reality; mathematics as a human activity.

\section{Social Arithmetic}

Consider the figure 3 below. Figure 3 shows a fishing village atmosphere in the absence of fishing activities in the sea. The parents are assisted by their children should mend the nets or boat engines as a form of preparation for fishing at night. Even at noon time, children have less time to go to school because they have to help their parents for taking care of their boat or their fishing tools.

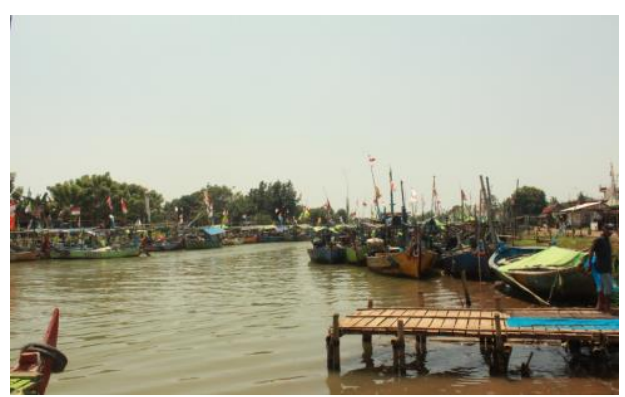

Figure 3. Atmosphere of a fishermen village (Resource: Documentation of Research Team at Coastal of Sikucing - Indonesia)

One of the uses of mathematics in everyday life of the fishermen is the Social Arithmetic. At the time if the fishermen returning from catching of fishes in the sea, the fishermen can sell their catch of fish in the fish market. Figure 4 and Figure 5 illustrate how a fisherman family daily life. They look for fish in the sea and then sell it at a fish market. 


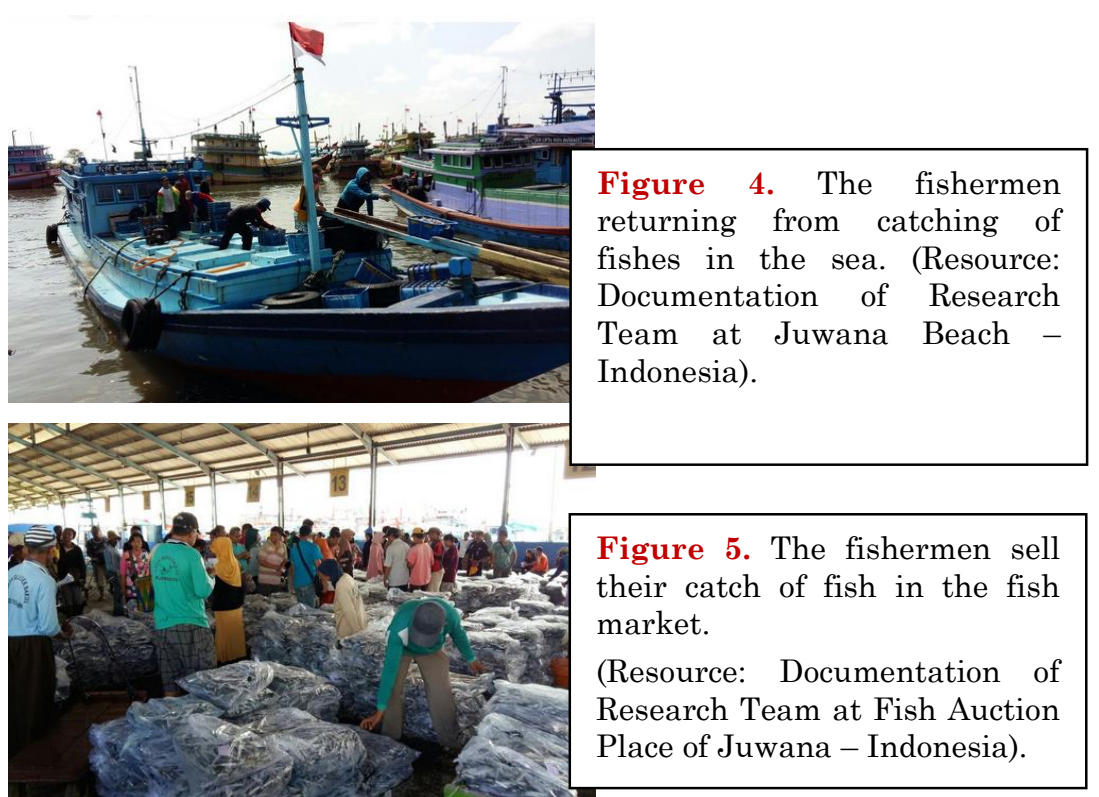

Children, please look at the picture above. If you manage to get a lot of fish while catching of fishes in the sea, then you can sell them at the Fish Market. Thus, you need to know the terms in the trade world such as the purchase price or buying price, selling price, profit, loss, discount, and so on. The following below will be explained the terms in the trading world.

1. Buying price. It is the price paid by a seller to a retailer (the capital)

2. Selling price. It is the price determined by a seller or the money received by a seller on a given transaction.

3. Profit. A seller gets profit when the selling price is greater than the buying price.

Profit $=$ selling price - buying price.

4. Loss. A seller suffers loss when the selling price is less than the buying price.

Loss $=$ buying price - selling price

Example:

1) A fisherman selling his catch of 100 fish at a price of $R p 100,000$,to a fish trader at the Fish Market. The trader then sold at retail in the traditional market. By trader, every four fish sold at $R p$ 5.000, - Finally, all the fish were sold out. Does he make loss or profit? How much is it?

Given: Buying price for 100 fishes $=\operatorname{Rp} 100.000$

Selling price for 4 fishes $=\operatorname{Rp} 5.000$

Question: Does he make loss or profit? How much is it?

Answer:

Selling price for 4 fishes $=\operatorname{Rp} 5.000$

Selling price for 100 fishes $=25 \times \operatorname{Rp} 5.000=\operatorname{Rp} 125.000$ 
In fact, selling price $>$ buying price. So, the trader gets profit.

Profit $=$ selling price - buying price

$$
\begin{aligned}
& =125.000-100.000 \\
& =25.000
\end{aligned}
$$

So, the pedagang gets profit $\operatorname{Rp} 25.000$

2) Look at figure 6 below. Mrs. Emi buys fish at TPI Juwana. The purchase price for $8 \mathrm{~kg}$ of fish is Rp96.000,00. If $8 \mathrm{~kg}$ fish is sold at the price of Rp15.000,00 per kg, then find out the percentage of profit or loss on the sale of the fish.

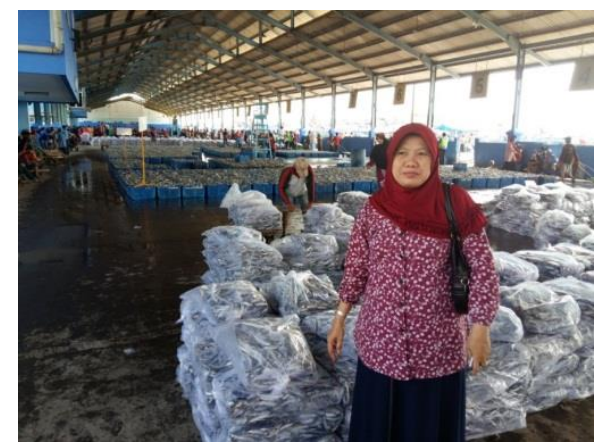

Figure 6. Mrs. Emi buys fish at Fish Auction Place of Juwana (Resource: Documentation of Research Team at Coastal of Juwana - Indonesia)

Given:

Buying price for $8 \mathrm{kgs}$ of fish is Rp $96.000,00$

Selling price for $8 \mathrm{kgs}$ of fish is $8 \times \mathrm{Rp} .15 .000,00=\mathrm{Rp} \cdot 120.000,00$

Question: Does Mrs. Emi make loss or profit? How many percent is it?

Answer:

In fact, selling price $>$ buying price. So, Mrs. Emi gets profit.

Profit $=$ selling price - buying price

$$
\begin{aligned}
& =\text { Rp. } 120.000,00-\operatorname{Rp} .96 \cdot 000,00 \\
& =\text { Rp. } 24 \cdot 000,00
\end{aligned}
$$

The percentage of profit $=\frac{R p \cdot 24 \cdot 000,00}{R p \cdot 96 \cdot 000,00} \times 100 \%$

$=\frac{1}{4} \times 100 \%=25 \%$

$=25 \%$

The Result of a Limited Test 
To view the legibility of Mathematical supplements' book which based on the coastal culture, then the research team has conducted a limited test to supplemental math books produced.

Based on the analysis with a qualitative approach, the results are as follows: (1) The teacher can understand every sentence of this supplement book. (2) Students can understand every sentence contained in the supplement book. (3) The materials and problems contained in the book supplement are in accordance with the basic competencies that exist in Curriculum 2013. (4) The solution of problems contained in the book supplement are reached by the students. (5) The contents of the book, both the material and the problems are equivalent to the Mathematics Books for Students issued by the Ministry of Education and Culture of the Republic of Indonesia.

\section{Conclusion}

Based on the explanation above it can be concluded that based on field surveys at coastal culture, many fishing families pay less attention to the education of their children. The parents were not informed about the benefits of the school, particularly the benefits of math. Therefore, it is necessary for socialization of the need for children to attend school. Other than that, it is necessary to prepare a book a supplementary book of mathematics teachinglearning process based-on coastal culture. Supplementary books which constitute this textbook need to be examined in advance in order to have significant benefits for the families of fishermen in coastal areas.

This research had produced a supplementary book of mathematics teaching-learning process based-on coastal culture. This book was developed through the process of searching for data in coastal areas, through FGD discussed among the research team with lecturer partners from UKM (Universiti Kebangsaan Malaysia). Thus, the novelty value of this study can show that mathematics can have benefits in the lives of fishermen, it is expected that the school could become the foundation for improving the pattern of community life of the fishermen environment in the future for their children.

\section{Notes on contributors}

Zaenuri - Prof. Dr. M.Si., Faculty of Mathematics and Natural Sciences, Universitas Negeri Semarang

Hardi Suyitno- Prof. Dr. M.Pd., Faculty of Mathematics and Natural Sciences, Universitas Negeri Semarang

Fathur Rokhman - Prof. Dr., M.Hum._Faculty of Language and Art, Universitas Negeri Semarang

Amin Suyitno-Drs. M.Pd.,_Faculty of Mathematics and Natural Sciences, Universitas Negeri Semarang

\section{References}

Bishop, A.J. (1994). Cultural Conflicts in Mathematics Education: Developing a Research Agenda. For the Learning Mathematics. Vol. 14 No. 2. 
Eraslan, Meric. (2014). The Analysis of the Thinking Styles and Creativity of the Sports Students Studying in the Different Fields of University. Academic Journal: Educational Research and Reviews. Vol. 9 (20). 23 October 2014.

Freudenthal. (1991). Revisiting Mathematics Education. China Lectures. Dordrecht Kluwer: Academic Publishers.

Gagne, R.M. (1983). Some Issue in Psychology of Mathematics Instruction. Journal for Research in Mathematics Education. 14(1).

Gerdes, P. (1988). On Culture, Geometrical Thinking, and Mathematics Education. Educational Studies in Mathematics. Vol. 19: 137-162

Gerdes, P. (1996). "On Ethnomathematics and the Transmission of Mathematical Knowledge In and Outside Schools in Africa South of the Sahara."Les Sciences Hors D'occidentali Me Siecle. (5): 229-246.

Gomez, Jose G. (2007). What Do We Know About Creativity?. The Journal of Effective Teaching, Vol. 7, No.1, 2007,31-34.

Güzel, Hatice. (2004). The Relationship Between Students' Success in Physics Lessons and Their Attitudes Towards Mathematics. Journal of Turkish Science Education. Volume 1, Issue 1, July 2004.

Howell, Beth. (2008). Some Student Teachers' Conceptions of Creativity in Secondary School English. English Language Teaching, Vol. 1 No.2, December 2008.

Lipka, J. and Irhke, D. A. (2009). "Ethnomathematics applied to classrooms in Alaska: Math in a Cultural Context."

Nadjafikhah, M, et al. (2012). Mathematical creativity: some definitions and characteristics. Procedia-Social and Behavioral Sciences: Elsevier. Available online at www.sciencedirect.com.

Nutti, Ylva Jannok. (2013). Indigenous teachers'experiences of the implementation of culture-based mathematics activities in Sámi school. Math Ed Res J (2013) 25:57-72. DOI 10.1007/s13394013-0067-6

Schoenfield, AH. (1987). What's all the fuss about metacognition? In AH Schoenfield (Ed). Cognitive Science and Mathematics Education, Hillslide, NJ: Lawrence Erlbaum Associates.

Schoenfield, AH. (1992). Learning to think mathematically: Problem solving, metacognition, and sense making in mathematics, In DA Grows (Ed). Handbook of Research on Mathematics Teaching and Learning: NCTM. New York: Macmilan Publishing Company.

Suyitno, Hardi. (2014). Pengenalan Filsafat Matematika. Semarang: Penerbit FMIPA Universitas Negeri Semarang.

Uloko, E.S. \& Imoko, B. I. (2007). "Effects of ethno mathematics teaching approach and gender on students' achievement in Locus." Journal National Association Social Humanity Education. 5 (1): 31-36.

UNESCO. 1998. Education For the Twenty-first Century: Issues and Prospect. UNESCO Publishing.

Uzoğlu, Mustafa and Büyükkasap, Erdoğan. (2011). The Relationship Between Seventh Grade Students' Intelligence Areas And Their Academic Success In Science And Mathematics. Journal of Turkish Science Education. Volume 8, Issue 3, September 2011.

Wang, Amber Yayin. (2011). Context of Creative Thinking: A Comparison on Creative Performance of Student Teachers in Taiwan and The United States. Journal of International and Crosscultural Studies, Volume 2, Issue 1, 2011. 